\title{
Foraging at a front: hydrography, zooplankton, and avian planktivory in the northern Bering Sea
}

\author{
Robert W. Russell*, Nancy M. Harrison **, George L. Hunt Jr \\ Department of Ecology and Evolutionary Biology, University of California, Irvine, California 92697-2525, USA
}

\begin{abstract}
We studied hydrographic structure, zooplankton distributions, and foraging by planktivorous seabirds in the Anadyr Strait, northern Bering Sea, during 4 summer cruises (1984-1986, 1993). The western portion of the strait was occupied by cold, dense Anadyr water that was mixed from top to bottom. This mixed water was separated from the stratified Bering Shelf water on the eastern side of the strait by a sharp surface front (the 'Anadyr Front'). Net sampling indicated that calanoid copepods were the numerically dominant component of the zooplankton, and that densities of several species were elevated in the frontal zone, apparently due to mechanical accumulation resulting from surface convergence. Hydroacoustic surveys showed that overall zooplankton biomass was concentrated along the thermocline and at the front. Although the location of the Anadyr Front was highly variable over time scales as short as $1 \mathrm{~d}$, large numbers of least auklets Aethia pusilla often flew 25 to $50 \mathrm{~km}$ from their breeding colonies to feed at the front. Diet samples indicated that the copepod Neocalanus plumchrus was the principal prey taken by least auklets both at the front and away from it, indicating that heavy use of the distant frontal habitat was due to the higher densities of their preferred prey (i.e. rather than absence of suitable prey species closer to shore). Whenever aggregations of least auklets were found away from the front, there was evidence that they were exploiting near-surface high-density patches of zooplankton, though the exact mechanisms responsible for the formation of such patches are unclear. In contrast to least auklets, crested auklets Aethia cristatella were usually found away from the front. In several cases, compact aggregations of crested auklets were located over acoustically observed epibenthic layers of zooplankton. Hydrographic data suggested that intense subsurface jets and/or upwelling along the eastern side of the strait might have increased the availability of the crested auklets' preferred euphausiid prey. Thus, spatial segregation of the 2 principal planktivores in Anadyr Strait likely arises because different physical mechanisms cause concentrations of preferred prey originating at different depths.
\end{abstract}

KEY WORDS: Front · Foraging - Bering Sea $\cdot$ Copepods - Neocalanus plumchrus - Least auklet Aethia pusilla $\cdot$ Crested auklet $\cdot$ Aethia cristatella

\section{INTRODUCTION}

Oceanic fronts are complex fluid structures often characterized by sharp sea-surface gradients in density, temperature, and/or salinity. Frontal phenomena include, but are not limited to, boundaries between different water masses. Distributed throughout the

Present addresses:

-Museum of Natural Science, 119 Foster Hall, Louisiana

State University, Baton Rouge, Louisiana 70803-3216, USA.

E-mail:migrants@hotmail.com

- Anglia Polytechnic University, East Road, Cambridge CB1

1PT, United Kingdom world's oceans, fronts occur at multiple spatial scales and have highly variable kinematics and flow fields (Fedorov 1986). Fronts have been noted by marine scientists and recorded in the literature for over 2 centuries (e.g. Franklin 1786, Darwin 1845, Beebe 1926), but have not been studied in ecological detail until recently. A growing body of evidence indicates that oceanic fronts support high levels of biotic activity across a wide range of trophic levels (reviewed by Le Fèvre 1986, Olson et al. 1994). Frontal enrichment or concentration has been documented in a wide variety of marine plankton, including microbes (e.g. Floodgate et al. 1981, Fernandez et al. 1994), phytoplankton 
(e.g. Iverson et al. 1979, Franks 1992a, Laubscher et al. 1993, Yoder et al. 1994), and zooplankton (e.g. Smith et al. 1986, Epifanio 1987)

Fronts also appear to be important components of the marine environment of predators at higher trophic levels. Schooling fishes may aggregate in fronts to feed on the plankton concentrations (e.g. Herron et al. 1989), and also perhaps to exploit the sharp thermal gradients for thermoregulation (Brandt \& Wadley 1981). Aggregations of large pelagic fishes such as tunas and swordfishes also have been documented in the vicinity of fronts (e.g. Dufour \& Stretta 1973, Carey \& Robison 1981, Fiedler \& Bernard 1987, Podestá et al. 1993). The nature of this frontal association has been controversial (reviewed by Olson \& Podestá 1987), because, although some fishes may feed at fronts (e.g. Fiedler \& Bernard 1987), others may use fronts as orientation cues for migration (e.g. Laurs \& Lynn 1977, Maul et al. 1984). Concentrations of pinnipeds and whales may also occur in the vicinity of fronts (e.g. Nasu 1974, Gaskin 1987, Brown \& Winn 1989, Sinclair et al. 1994), but have been little studied.

Large seabird concentrations at oceanic fronts have often been documented in the literature (reviewed by Hunt \& Schneider 1987, Schneider 1990, 1991), and these seem most straightforwardly interpreted as feeding aggregations. However, concentration of seabirds at fronts is often intermittent (e.g. Uda 1938, Hawke 1996). In a statistical analysis of the relationship between seabirds and fronts, Schneider et al. (1987) reported that, on average, seabird abundance was not significantly higher at fronts than in adjacent waters of the southeastern Bering Sea, though abundance was higher at strong fronts than at weaker fronts.

With local phytoplankton growth rates as high as $16 \mathrm{~g} \mathrm{C} \mathrm{m}^{-2} \mathrm{~d}^{-1}$ and estimated annual carbon production of $-500 \mathrm{~g} \mathrm{~m}^{-2}$, the northwestern Bering Sea (Fig. 1) is one of the most productive marine ecosystems in the world (Sambrotto et al. 1984, McRoy et al. 1987, Springer \& McRoy 1993). Together with this high primary productivity, the region is characterized by large standing stocks of zooplankton (Springer et al. 1989), an abundant benthic fauna (Highsmith \& Coyle 1990), large numbers of transient marine mammals (Fay et al. 1984, Johnson \& Nelson 1984, Nerini 1984, Nelson \& Johnson 1987, Obst \& Hunt 1990), and immense breeding colonies of seabirds on the area's islands (Fay \& Cade 1959, Sowls et al. 1978). This biological richness has been attributed in part to the northward transport of nutrient-rich oceanic water from the continental slope into the northern Bering Sea (Hansell et al. 1989, 1993, Springer \& McRoy 1993), which is caused by sea level differences between the Arctic Ocean and the Bering Sea (Stigebrandt 1984 , Coachman 1993). The northward flow, known as the 'Anadyr Current', passes along the Siberian coast on the western side of the Bering Sea and ultimately through the Bering Strait (Fig. 1; Coachman et al. 1975, Kinder et al. 1986, Overland et al. 1996). As it flows to the north, it carries with it an entire zooplankton community, including species that are more characteristic of deep oceanic waters (e.g. Eucalanus bungii and Neocalanus spp.; Johnson 1963, Springer et al. 1989). Indeed, the northern Bering Sea ecosystem has been likened to a chemostat (Sambrotto et al. 1984) or a conveyor belt (Springer \& Roseneau 1985).

The principal avian planktivores in the northern Bering Sea are auklets, of which the least auklet Aethia pusilla and crested auklet Aethia cristatella are the most abundant. Immense breeding colonies are located on St. Lawrence Island, King Island, and the Diomede Islands (Sowls et al. 1978). During the chickrearing period, these birds fly to sea to forage and return to colonies carrying loads of zooplankton in their sublingual pouch. Previous studies that have examined auklet diets and foraging habitat selection have suggested that these birds are dependent on prey found principally in Anadyr water and adjacent Bering Shelf water influenced by the Anadyr Current (Bédard

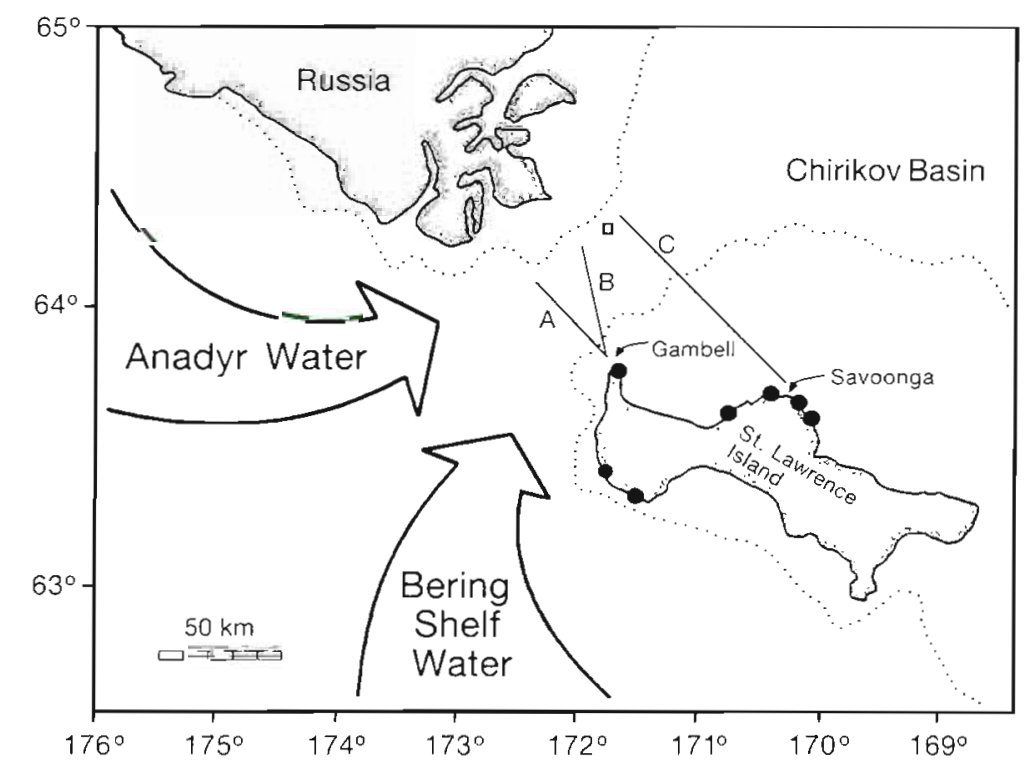

Fig. 1. Map of the study area showing the $30 \mathrm{~m}$ isobath (dotted lines), relative positions of the principal water masses, and locations of the 3 transect lines $(A, B, C)$. Small box near the end of Line $C$ shows the area of the finescale 2-dimensional study (see Fig. 5). Solid circles show the locations of large auklet colonies (>10000 birds) on St. Lawrence Island (based on Sowls et al. 1978) 
1969, Springer \& Roseneau 1985, Hunt \& Harrison 1990, Hunt et al. 1990, Piatt et al. 1992, Obst et al. 1995). Because the other water masses occupying the northern Bering Sea are not consistently inhabited by preferred prey species, it has been suggested that the large local breeding populations of auklets are supported solely by advection of food resources from farther south by the Anadyr Current (Springer \& Roseneau 1985).

The northward flow of the Anadyr Current is intensified by channeling through the Anadyr Strait, between St. Lawrence Island and Russia, before entering the Chirikov Basin north of St. Lawrence Island. Bering Shelf water also enters the Chirikov Basin through the Anadyr Strait, and a strong front (referred to hereafter as the 'Anadyr Front') delineates the boundary between the 2 water masses (Nihoul et al: 1993, Gawarkiewicz et al. 1994). In light of the available evidence on the impact of frontal zones, it seems likely that the Anadyr Front may concentrate zooplankton populations and therefore be an important foraging area for auklets. Previous workers have anecdotally reported massive concentrations of auklets in the Anadyr Strait (e.g. Gudkov 1962). However, with the exception of a single preliminary case study (Harrison et al. 1990), details on the ecological implications of the Anadyr Front are not available.

We studied the relationships between auklet foraging, zooplankton distributions, and the Anadyr Front during cruises to the northern Bering Sea in 1984, 1985, 1986, and 1993. This paper focuses on the following questions: (1) How predictably are auklets found near the front and where are they distributed in relation to the hydrographic structure? (2) Do predictable zooplankton distributions at the front draw the birds? and (3) What are the implications of frontal structure and location for the feeding ecology and life history of the birds?

\section{METHODS}

Hydrographic structure, zooplankton distributions, and auklet foraging in Anadyr Strait were studied along 3 transect lines emanating from points near major auklet breeding colonies on St. Lawrence Island (Fig. 1). Lines A and B originated just offshore from Gambell. The adjacent colony on Sevuokuk Mountain $\left(63^{\circ} 46.6^{\prime} \mathrm{N}, 171^{\circ} 41.0^{\prime} \mathrm{W}\right)$ is populated by about 111000 least auklets and 72000 crested auklets (Sowls et al. 1978). Line $C$ originated just offshore of Savoonga, near the colony at Kookoolik $\left(63^{\circ} 41.4^{\prime} \mathrm{N}, 170^{\circ} 18.6^{\prime} \mathrm{W}\right)$. The Kookoolik colony is populated by about 51000 least auklets and 34000 crested auklets (Sowls et al. 1978). Throughout the study, international politics precluded sampling west of the International Date Line, and all of our transects were terminated prior to a complete crossing of the strait.

Hydrographic data were collected by lowering a NeilBrown conductivity-temperature-depth (CTD) probe to within $5 \mathrm{~m}$ of the bottom while the ship was stopped at sampling stations along transects. Vertical and horizontal cross-sections of physical properties were contoured using the minimum curvature gridding algorithm in the Surfer Version 5.02 Surface Mapping System. For simplicity, we present only temperature contours here, as the distributions of temperature, salinity, and density were always very similar.

Subsurface distributions of zooplanton along the cruise transects were studied using a BioSonics echosounding system while the ship was underway between stations. The system was composed of a $200 \mathrm{kHz}$ model 101 echosounder and a model 120 echointegrator. The receiver gain was set at $6 \mathrm{~dB}$, the band width at $5 \mathrm{kHz}$, the absorption coefficient for $200 \mathrm{kHz}$, the range at $150 \mathrm{~m}$, the transmitter on $0 \mathrm{~dB}$, and the pulse width at $0.5 \mathrm{~m}$. Before each transect was initiated, the system was calibrated with an internal signal. The transducer was towed beside the ship and outside the wake in a V-fin depressor. Sonic surveys were conducted at a speed of $\sim 6$ knots. Signals were blanked to $5 \mathrm{~m}$ below surface to reduce noise, and echoes were integrated vertically in $2 \mathrm{~m}$ bins from $5 \mathrm{~m}$ below surface to the bottom. Each integration consisted of 100 pings and examined approximately $200 \mathrm{~m}$ of horizontal distance. Incoming signals were corrected for timevaried gain, digitized, and transferred to a microcomputer for further processing and analysis. We did not attempt to convert echo return voltages into estimates of absolute biomass because of uncertainties about the target strengths of the zooplankton constituents. Contour plots of zooplankton distribution were created from volume scattering measurements using Surfer with minimum curvature gridding.

Zooplankton community composition and species abundance were sampled by conducting vertical tows from just above the bottom to the surface with a $1 \mathrm{~m}$ diameter, $505 \mu \mathrm{m}$ mesh net at selected hydrographic stations. Zooplankton samples were preserved in $5 \%$ formaldehyde solution for later laboratory analysis. Identification of the taxa in these samples was completed before Neocalanus flemingeri was identified as a species distinct from Neocalanus plumchrus (Miller 1988), so densities of $N$. plumchrus reported in this paper may include an unknown proportion of the very similar $N$. flemingeri.

The distribution of auklets was studied by making continuous counts of birds on the water within $300 \mathrm{~m}$ of one side of the ship while the ship was underway. Many of our interpretations of observed auklet distrib- 
utions rely on the assumption that the majority of birds have commuted from St. Lawrence Island. Unfortunately, little information is available on the distribution or abundance of auklets on the Russian side of Anadyr Strait. We cannot discount the possibility that some of the birds observed during our transects had commuted from Russian colonies. However, we routinely observed vast flights of auklets flying northwestward away from St. Lawrence Island toward the Anadyr Front and southeastward from the front toward the island, indicating at least that many of the birds were Alaskan in origin.

Diets of least auklets were examined by collecting birds from a small boat at selected locations using a 12-gauge shotgun. Contents of the stomach and gular pouch were removed immediately following collection and preserved in $80 \%$ ethanol. Prey samples were later sorted and identified in the laboratory.

The energetic value of selected potential prey species was determined from zooplankton samples collected in the southern Bering Sea, just north of the central Aleutian Islands, during a cruise in June 1995. Following determinations of chemical composition, the energy value of fresh prey biomass was calculated assuming that the metabolizable energy yields of protein and fat are $18.04 \mathrm{~kJ} \mathrm{~g}^{-1}$ and $39.54 \mathrm{~kJ} \mathrm{~g}^{-1}$, respectively, for uricotelic organisms (Bell 1990).
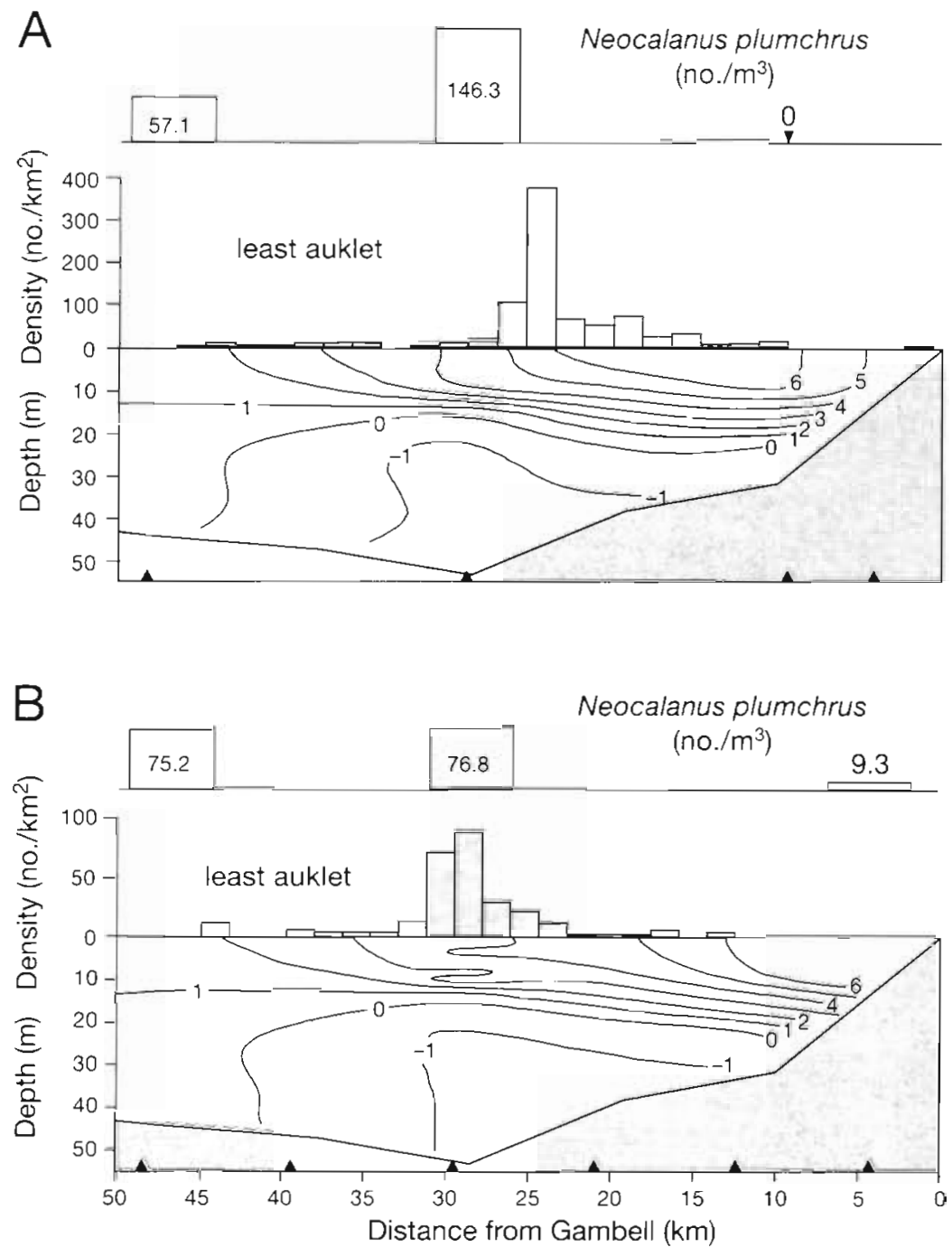

Fig. 2. Transects along Line A in 1984 showing copepod abundance from net tows (top panels), least auklet abundance (middle panels), and thermal structure of the water column $\left({ }^{\circ} \mathrm{C}\right)$ from CTD casts (bottom panels). Locations of hydrographic stations are marked by triangles along the bottom of the panels showing CTD contours. (A) Afternoon of July 9 (14:20-16:59 h local time). (B) Afternoon of July 10 (14:51-16:59 h local time)

\section{RESULTS}

\section{Distributions of auklets and copepods along transects}

We conducted 2 replicate transects along Line A northwestward from Gambell on July 9-10, 1984. On the first transect (afternoon of July 9), a concentration of least auklets was evident at the island-ward edge of the Anadyr Front, $\sim 25 \mathrm{~km}$ from Gambell, although a number of birds were also present closer to the island on the adjacent, stratified, Bering Shelf water (Fig. 2A). Net tows indicated that high densities of Neocalanus plumchrus were present in the vicinity of the concentration of auklets at the front (Fig. 2A). On our second transect along this line the following morning, the front had moved closer to St. Lawrence Island and occupied a broad zone in the strait. A concentration of least auklets was again present in the frontal zone; however, while the front had moved closer to the birds' breeding areas, the birds were feeding farther away than during the previous transect, in an area where hydrographic data revealed the presence of fine-scale structure in the water column (Fig. 2B).

We repeated a single transect along Line $A$ on August 9,1985 . During this survey, the surface manifestation of the front occurred west of the International Date Line and auklet densities were relatively low in the survey area (Fig. 3). The hydroacoustic survey 
showed a dense layer of zooplankton along the thermocline, and least auklets were concentrated in an area where the hydroacoustic data indicated that zooplankton were being entrained from the thermocline to the surface (Fig. 3).

We conducted 3 replicate transects along Line A northwestward from Gambell on August 11-12, 1986 On the first run during the afternoon of August 11, the front apparently was located close to Russia and our transect did not reach it. Nevertheless, we found a large concentration of least auklets over the deepest portion of the strait, $-33 \mathrm{~km}$ from Gambell (Fig. 4A). A concentration of crested auklets was evident closer to the island at a point where the thermocline domed upward (Fig. 4A). The concurrent hydroacoustic survey indicated that 2 layers of zooplankton were present: a midwater layer along the thermocline away from the island, and an epibenthic layer below $30 \mathrm{~m}$ near the island. There were indications of surface entrainment of zooplankton as the front was approached,

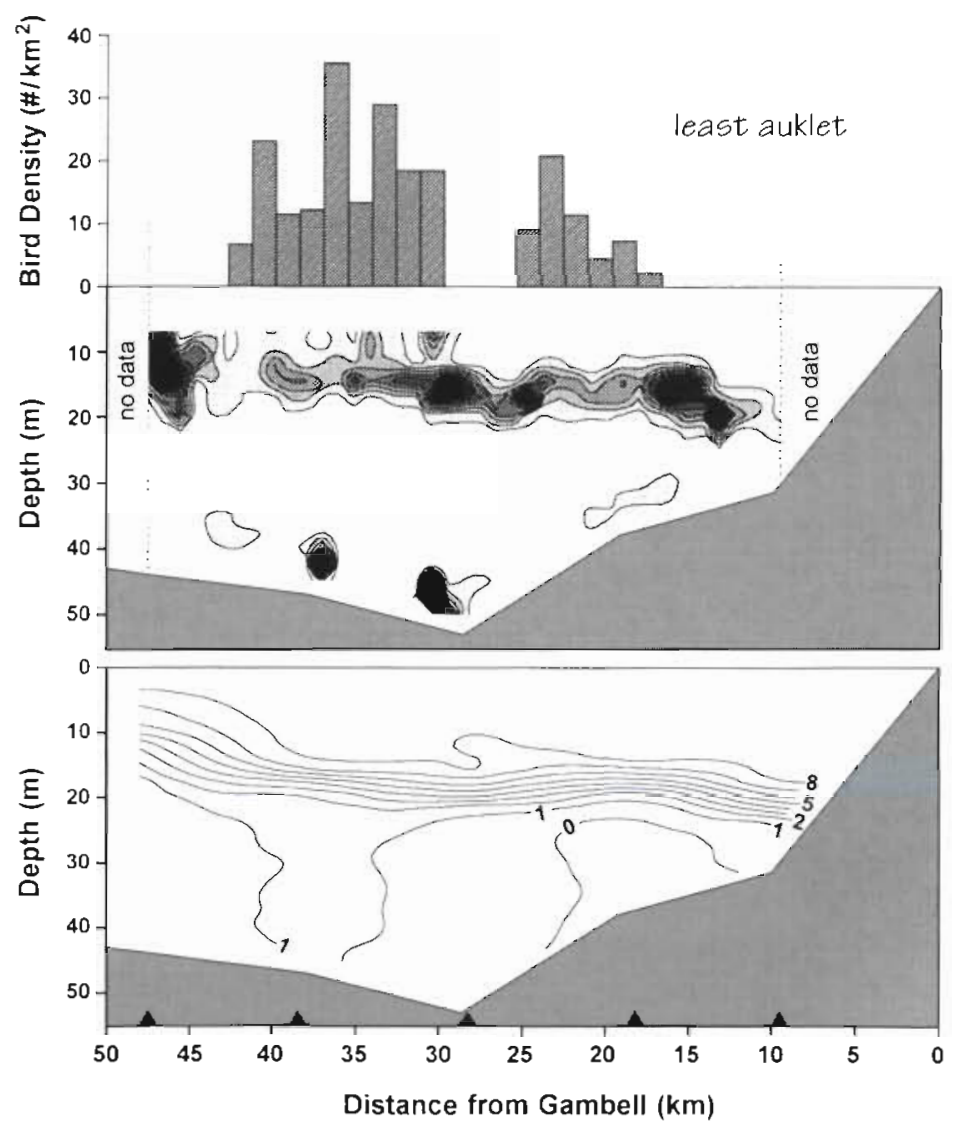

Fig. 3. Transect along Line A on August 9, 1985 (08:45-13:39 h local time). Top panel shows least auklet abundance, middle panel shows relative distribution of zooplankton biomass from a hydroacoustic survey (darker shades of gray indicate greater biomass density), and bottom panel shows thermal structure of the water column $\left({ }^{\circ} \mathrm{C}\right)$ from CTD casts. Locations of hydrographic stations are marked by triangles along the bottom of the panel showing CTD contours and the concentration of least auklets was over an apparent surface concentration of prey (Fig. 4A). The crested auklets were near but not directly over another apparent surface concentration of zooplankton, and instead seemed to be more closely associated with the epibenthic layer (Fig, 4A)

The second transect was run on the same day but later in the evening. The hydroacoustic survey showed a continuous scattering layer along the thermocline (Fig. 4B), with no evidence of the epibenthic layer detected during the previous survey (cf. Fig. 4A). As during the previous survey, a dense surface patch of zooplankton attracted large numbers of least auklets, but a smaller concentration of least auklets was also evident at the Russian end of the line, where CTD data indicated that the thermocline was beginning to rise to the surface and the front was rapidly moving eastward into the study area (Fig. 4B). Also at this time, the upward deformation of the thermocline near the island had apparently relaxed; although a few crested auklets were still present in the vicinity as before, the concentration had clearly dispersed (Fig. 4B).

The third and final transect in this series was conducted on the afternoon of the following day. At that time, the front had moved into our study area and was apparent at the northwest end of the line, $45 \mathrm{~km}$ from Gambell. A massive concentration of least auklets was found feeding at the front (Fig. 4C). Few crested auklets were observed during this transect. Five net tows along the line indicated that the highest densities of Neocalanus plumchrus $\left(\sim 78\right.$ ind. $\left.\mathrm{m}^{-3}\right)$ were present in the vicinity of the front (Fig $4 \mathrm{C}$ ). Least auklets were apparently overflying $N$. plumchrus densities of -37 ind $\mathrm{m}^{-3}$ and even higher densities of Calanus marshallae ( -59 ind. $\mathrm{m}^{-3}$ ) to reach the frontal concentration of $N$. plumchrus (Fig. 4C).

Late in the day on August 12, 1986, we conducted a fine-scale study of horizontal frontal structure and auklet distribution near the end of Line C (Fig. 5). Extremely large numbers of least auklets were foraging directly within the frontal zone, and appeared to be concentrated in a frontal meander (Fig. 5).

We returned to the Anadyr Strait in 1993 and performed 1 transect along Line B northwestward from Gambell on June 15. At that time, much of the frontal zone was apparently located slightly beyond the International Date Line and we were forced to stop just short of crossing it. Nevertheless, it was clear that large numbers of least auklets were 

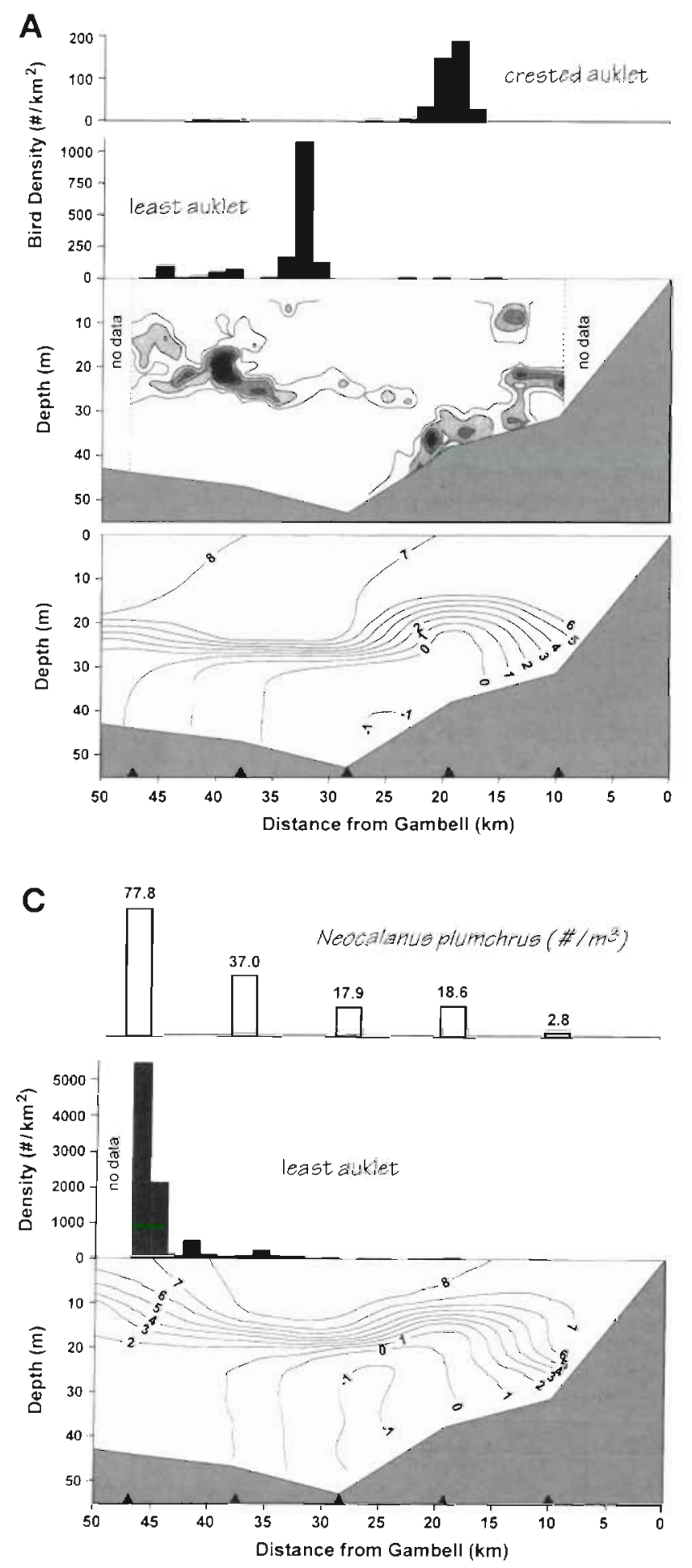

concentrated at the front (Fig. 6). Crested auklets were also present in large numbers on this transect, and there was a remarkably sharp spatial separation between the 2 auklet species. All crested auklets were feeding to the St. Lawrence Island side of the concentration of the least auklets, near the deepest part of the strait (Fig. 6).

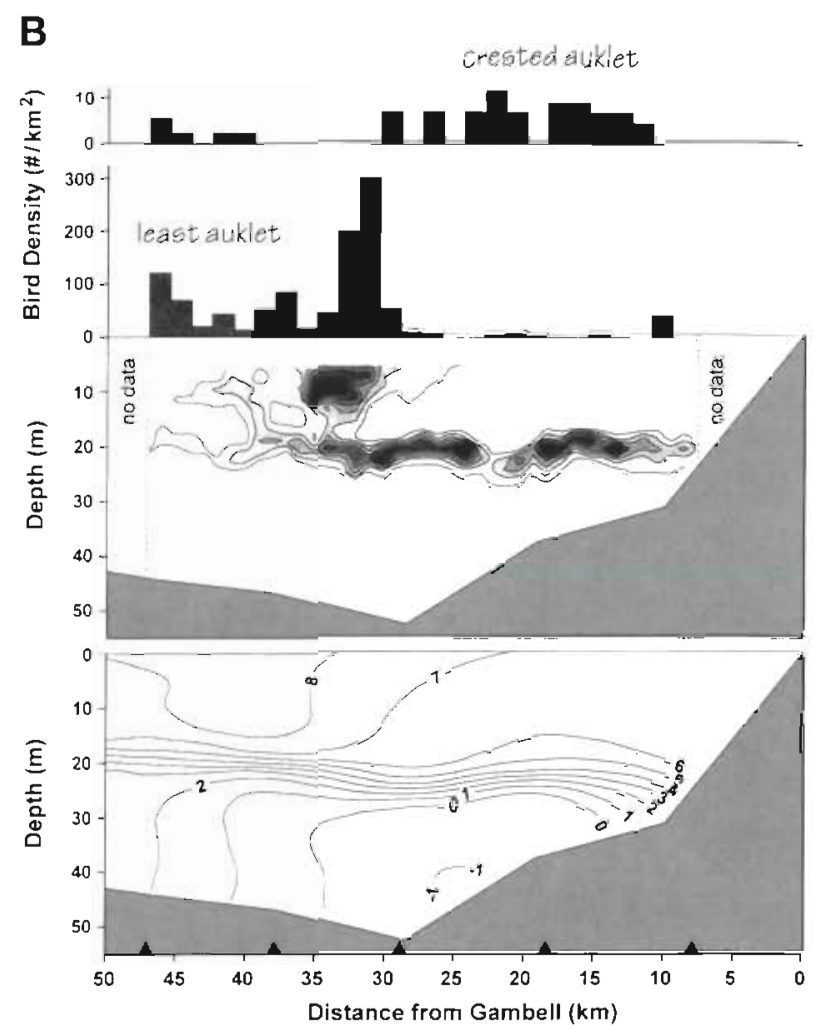

Fig. 4. Three transects along Line A on August 11-12 in 1986 Locations of hydrographic stations are marked by triangles along the bottom of the panels showing CTD contours. (A) Late afternoon of August 11 (16:56-19:38 h local time) and (B) late evening of August 11-12 (23:46-03:25 h local time). Top panels show auklet abundance, middle panels show relative distribution of zooplankton biomass from a hydroacoustic survey, and bottom panels show thermal structure of the water column $\left({ }^{\circ} \mathrm{C}\right)$ from CTD casts. (C) Late afternoon of August 12 (16:16-19:06 h local time). Top panel shows copepod abundance from net tows, middle panel shows least auklet abundance, and bottom panel shows thermal structure of the water column $\left({ }^{\circ} \mathrm{C}\right)$ from CTD casts

We conducted our first transect along Line C running northwestward from Savoonga on the north side of St. Lawrence Island during the afternoon of August 4, 1985. A sharp front was present $\sim 70 \mathrm{~km}$ from Savoonga, but densities of least auklets were not obviously elevated in the frontal zone (Fig. 7). Peak densities of least auklets occurred only $\sim 30 \mathrm{~km}$ from the island, over the point closest to the island where the thermocline still was strong (i.e. the CTD data suggested mixing closer to island). A net tow indicated high densities of Neocalanus plumchrus (171 ind. $\mathrm{m}^{-3}$ ) in the vicinity of the least auklet concentration (Fig. 7). Two small aggregations of crested auklets were also present beyond the peak concentration of least auklets, one over the shallow thermocline and one at the nearshore edge of the front (Fig, 7). 


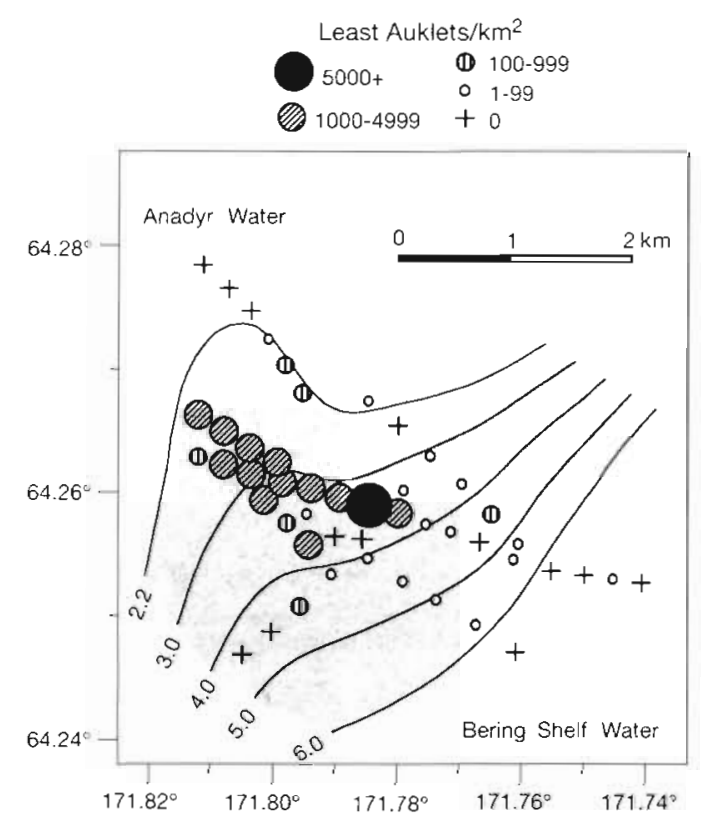

Fig. 5. Fine-scale 2-dimensional study near the end of Line $C$ on August 12, 1986 (21:52-00:02 h local time). Shaded area: Anadyr Front. Least auklet abundance is shown in relation to the distribution of near-surface $\left(5 \mathrm{~m}\right.$ depth) temperature $\left({ }^{\circ} \mathrm{C}\right)$ determined from CTD casts. The area encompassed by the figure is indicated by the small box in Fig. 1

We ran a series of 3 transects along Line $\mathrm{C}$ on August 11, 12, and 13, 1985. On August 11, the front was encountered $\sim 90 \mathrm{~km}$ from Savoonga, and therefore had moved $-20 \mathrm{~km}$ west since the previous survey $1 \mathrm{wk}$ before (Fig. 8A; cf. Fig. 7). Least auklets were not abundant along this transect, but a sharp concentration nevertheless was evident in the frontal area (Fig. 8A).

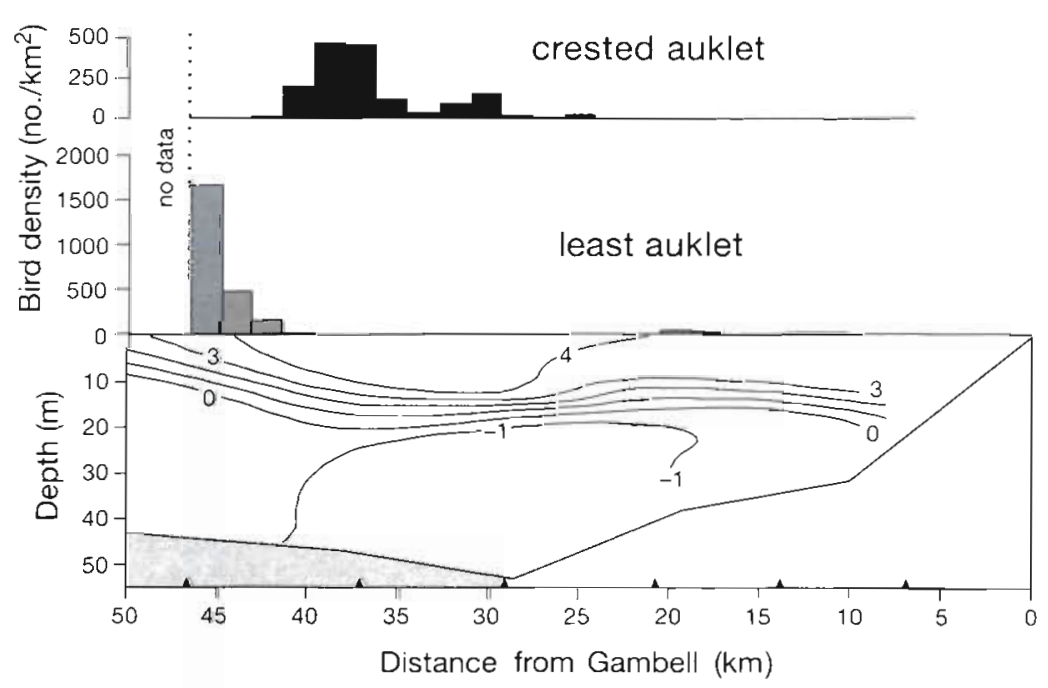

Fig. 6. Transect along Line B on June 15, 1993 (18:14-20:05 h local time). Upper panels show auklet abundance, and bottom panel shows the thermal structure of the water column $\left({ }^{\circ} \mathrm{C}\right)$ from CTD casts. Locations of hydrographic stations are marked by triangles along the bottom of the panel showing CTD contours

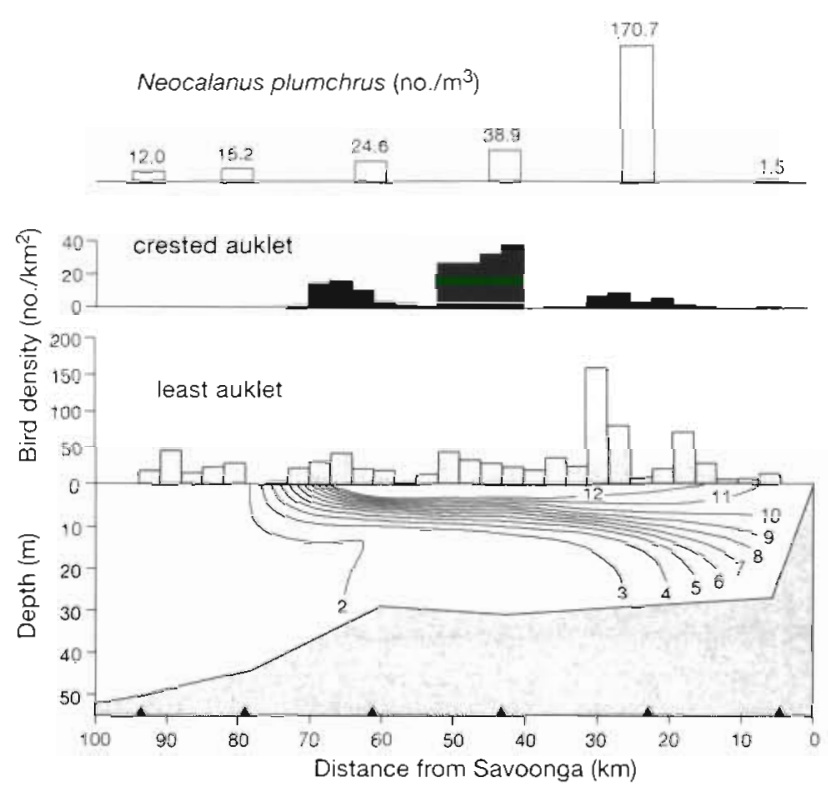

Fig. 7. Transect along Line C on August 4, 1985 (15:25-21:47 h local time). Top panel shows copepod abundance from net tows, middle panels show auklet abundance, and bottom panel shows thermal structure of the water column $\left({ }^{\circ} \mathrm{C}\right)$ from CTD casts. Locations of hydrographic stations are marked by triangles along the bottom of the panel showing CTD contours

In contrast to most of the other transects, peak numbers of least auklets apparently were feeding on the side of the front abutting Anadyr water, rather than near the shelf-water edge of the front (Fig. 8A). Small numbers of crested auklets were present along the offshore half of the transect, with a suggestion of a concentration in the frontal zone but separated from and slightly islandward of the least auklets (Fig. 8A).

The second transect in this series was conducted on August 12 at a finer spatial resolution. The geographic distribution of birds was very similar to the previous transect but the front had moved $>5 \mathrm{~km}$ closer to the island. As a result, the concentration of least auklets was $\sim 5 \mathrm{~km}$ northwest of the front, over fully mixed Anadyr water, whereas the crested auklets were closer to the front (Fig, 8B). The concurrent hydroacoustic survey showed a strong concentration of zooplankton in the front (Fig. 8B).

By the final transect in this series on the following morning, the front had moved even closer to St. Lawrence Island and was $-75 \mathrm{~km}$ from Savoonga. Least auklets were scattered along the line but most birds were loosely concentrated near the front (Fig. 8C). The hydroacoustic survey revealed a strong 

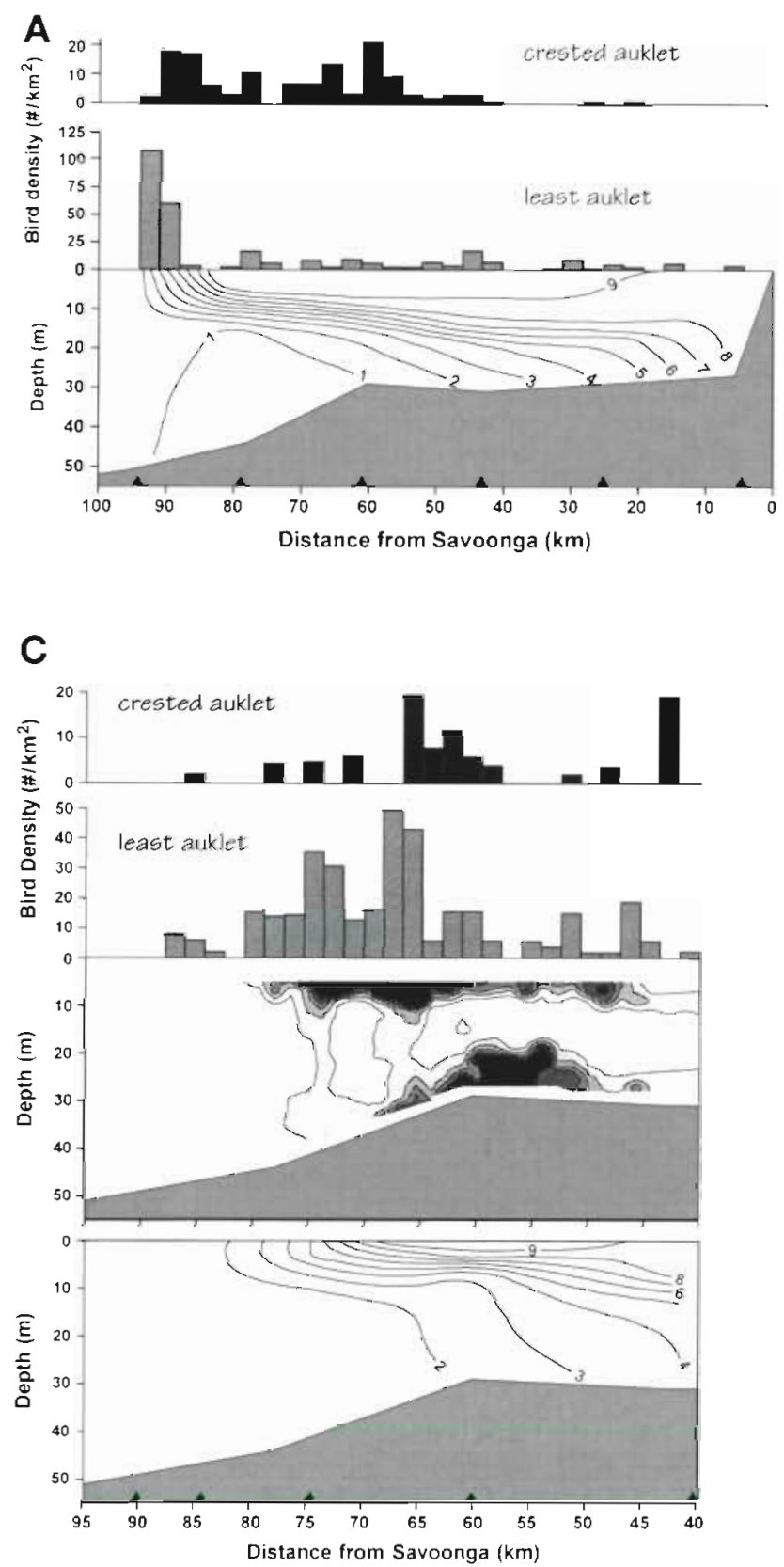

scattering layer along the shallow thermocline, and peaks in least auklet density were clearly associated with 2 strong surface concentrations of zooplankton in the vicinity of the front. A small concentration of crested auklets was evident just island-ward of the front and away from the majority of least auklets (Fig. 8C). These crested auklets appeared to be exploiting an epibenthic concentration of zooplankton (Fig. 8C).

We returned to Line C in 1986 and conducted transects during the mornings of August 12 and 13. On August 12 , the front was present $\sim 90-95 \mathrm{~km}$ from St. Lawrence Island and a small concentration of least auklets was evident there (Fig 9A). A larger concen-

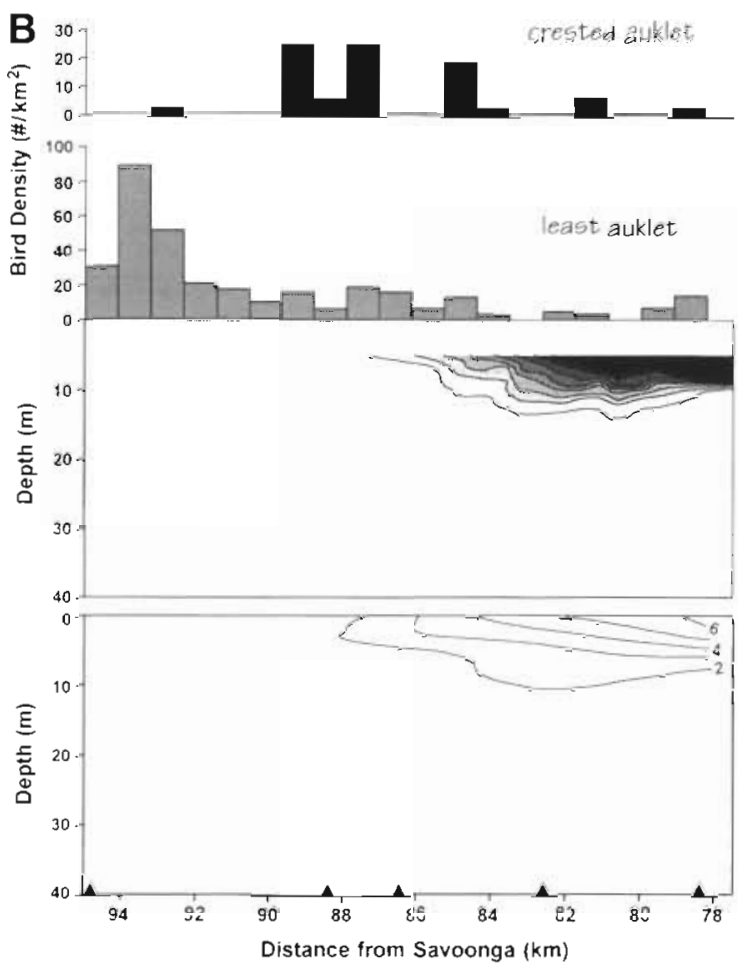

Fig. 8. Transects along Line $C$ on August 11-13, 1985. Locations of hydrographic stations are marked by triangles along the bottom of the panels showing CTD contours. (A) Afternoon of August 11 (14:28-19:51 h local time). Upper panels show auklet abundance, and bottom panel shows the thermal structure of the water column $\left({ }^{\circ} \mathrm{C}\right)$ from CID casts. (B) Late afternoon on August 12 (18:15-20:53 h local time) (note the finer scale of these observations compared to Fig. $8 \mathrm{~A})$ and (C) morning of August 13 (08:47-14:22 h local time). Upper panels show auklet abundance, middle panels show the relative distribution of zooplankton biomass from hydroacoustic surveys, and bottom panels show thermal structure of the water column $\left({ }^{\circ} \mathrm{C}\right)$ from $(\mathrm{T} D$ casts

tration of crested auklets was located closer to the island, though no distinctive hydrographic features were evident (Fig. 9A). The front had not changed position by the following day, and a large concentration of least auklets was located near the edge of the front abutting Anadyr Water (Fig. 9B). Very few crested auklets were observed during this transect.

\section{Zooplankton abundance}

Net tows indicated that the copepod Eucalanus bungii was the most abundant species in the front as 


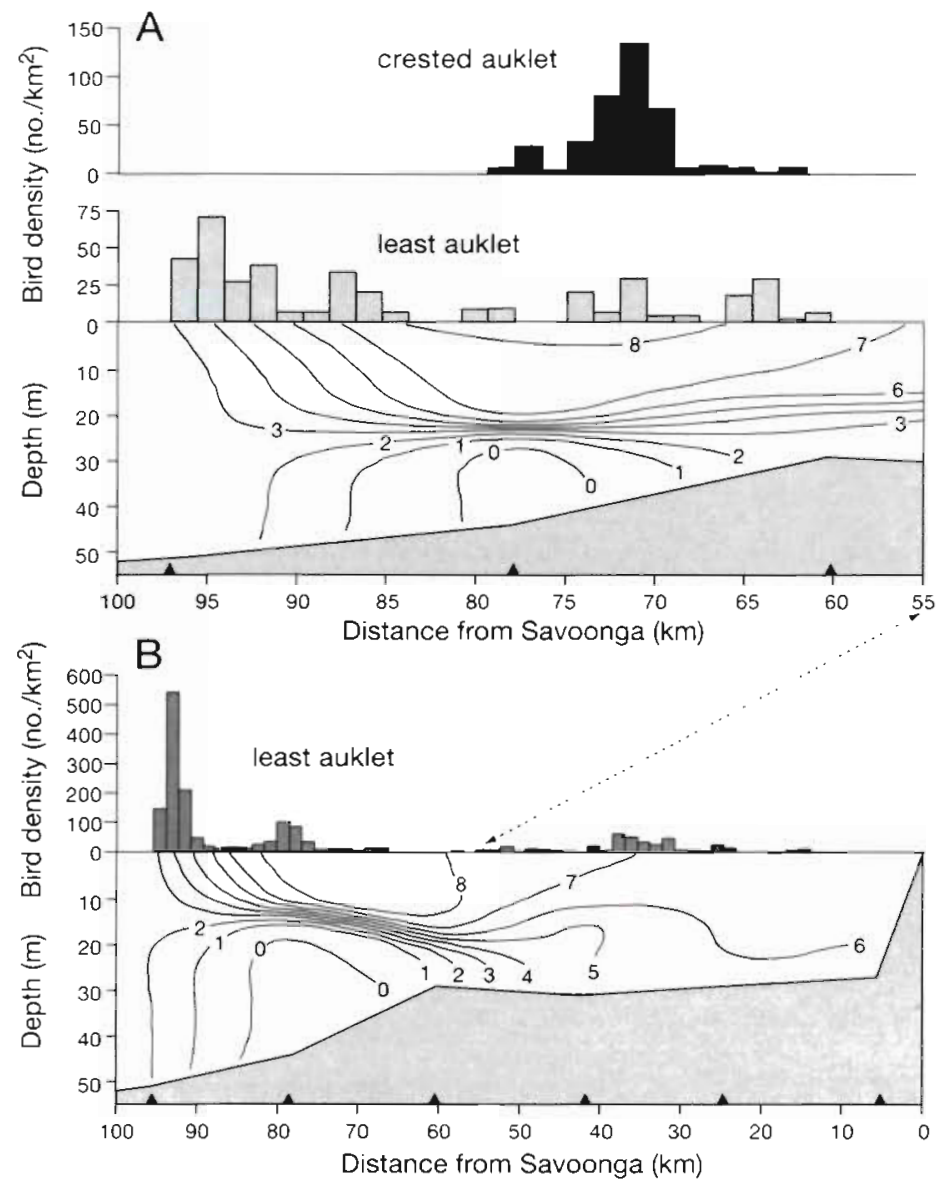

Fig. 9. Transects run along Line C on August 12-13, 1986. Upper panels show auklet abundance, and bottom panels show the thermal structure of the water column $\left({ }^{\circ} \mathrm{C}\right)$ from CTD casts. Note the horizontal scale difference between the 2 transects. Locations of hydrographic stations are marked by triangles along the bottom of the panels showing CTD contours. (A) Morning of August 12 (04:51-06:53 h local time). (B) Morning of August 13 (02:38-07:25 h local time) shelf water. Densities of other species did not vary significantly among water masses.

\section{Auklet diets}

Diet samples collected from least auklets feeding in Bering Shelf water and at the Anadyr Front are summarized in Table 2. A diverse array of zooplankters occurred in least auklet diets, but Neocalanus plumchrus was the dominant prey item in auklet diets both at the front and elsewhere. Crested auklets were not sampled for diet.

Mean metabolizable energy values of the principal copepod species available to least auklets were $5.36 \mathrm{~kJ} \mathrm{~g}^{-1}$ for Neocalanus cristatus ( $\pm 1.31 \mathrm{SE}, \mathrm{n}=4$ determinations), $4.95 \mathrm{~kJ}$ $\mathrm{g}^{-1}$ for $N$. plumchrus $( \pm 0.52 \mathrm{SE}, \mathrm{n}=4)$, and $2.02 \mathrm{~kJ} \mathrm{~g}^{-1}$ for Eucalanus bungii $( \pm 0.49 \mathrm{SE}, \mathrm{n}$ $=4)$. Energy value differed significantly among these 3 species (1-way ANOVA: $F_{2,9}=$ $4.45, \mathrm{p}=0.045$ ).

\section{DISCUSSION}

Our repeated crossings of the Anadyr Strait revealed common patterns in hydrography, zooplankton distribution, and auklet distribution. The western portion of the strait is occupied by cold dense Anadyr water from top to bottom. Where this mixed water interfaces with the stratified Bering Shelf water, the thermocline rises and forms a sharp surface front. Consistent with previous studies well as in both of the adjacent water masses (Table 1). Among the principal components of the zooplankton, the copepods Neocalanus plumchrus and $E$. bungii as well as the chaetognath Sagitta elegans - a copepod predatoroccurred at the front in significantly elevated densities. Metridia pacifica appeared to be about equally abundant in Anadyr water and at the front, but was significantly less abundant in shelf water. Pseudocalanus spp. appeared to be much more abundant at the front than elsewhere, but these smaller copepods were not sampled adequately by our nets so we did not conduct statistical tests. In contrast, copepodids were most abundant in
Table 1. Densities of zooplankton species in relation to water type in the Anadyr Strait. Data are shown for all taxa recorded with mean densities exceeding 1 ind $\mathrm{m}^{-3}$. Oikopleura spp. and Pseudocalanus spp. were abundant in net samples but not enumerated. Values shown are raw means, with standard errors in parentheses. P-values are from 1-way analyses of variance (ANOVAs). All data were log-transformed prior to ANOVA due to heteroscedasticity

\begin{tabular}{|c|c|c|c|c|}
\hline \multirow[t]{2}{*}{ Species } & \multicolumn{3}{|c|}{ Density (ind. $\mathrm{m}^{-3}$ ) } & \multirow[t]{2}{*}{$\mathrm{p}$} \\
\hline & $\begin{array}{l}\text { Anadyr } \\
\text { water }\end{array}$ & $\begin{array}{l}\text { Anadyr } \\
\text { Front }\end{array}$ & $\begin{array}{c}\text { Bering Shelf } \\
\text { water }\end{array}$ & \\
\hline Neocalanus plumchrus & $43.4(10.4)$ & $66.4(16.1)$ & $31.0(16.1)$ & 0.051 \\
\hline Neocalanus cristatus & $2.3(1.2)$ & $2.3(1.5)$ & $1.4(0.6)$ & 0.83 \\
\hline Eucalanus bungii & $58.0(34.9)$ & $343.0(133.7)$ & $52.1(30.0)$ & 0.010 \\
\hline Calanus marshallae & $8.4(3.8)$ & $22.4(11.1)$ & $15.5(6.0)$ & 0.64 \\
\hline Metridia pacifica & $13.1(6.1)$ & $10.1(3.7)$ & $2.0(1.4)$ & 0.052 \\
\hline Calanoid copepodids & $18.6(6.4)$ & $33.3(7.8)$ & $132.1(40.5)$ & 0.059 \\
\hline Euphausidd furcilia & $1.7(0.7)$ & $34.5(17.8)$ & $25.6(11.1)$ & 0.19 \\
\hline Aglantha digitalis & $0.1(0.1)$ & $7.4(6.6)$ & $14.2(11.1)$ & 0.33 \\
\hline Sagitta elegans & $0.8(0.6)$ & $13.4(4.1)$ & $5.6(3.8)$ & 0.006 \\
\hline Sample size (no. of tows) & 6 & 7 & 10 & \\
\hline
\end{tabular}


Table 2. Diet samples obtained from least auklets collected from feeding flocks on Bering Shelf water and at the Anadyr Front All birds were collected from 00:02-01:22 h local time on August 13, 1986, immediately following the completion of the finescale 2-dimensional study (Fig. 5). Values shown are the numbers of identifiable prey items in each sample, $x$ : present but not quantifiable

\begin{tabular}{|c|c|c|c|c|c|c|c|c|c|c|c|c|c|c|c|}
\hline \multirow[t]{2}{*}{ Prey species } & \multirow[b]{2}{*}{1} & \multicolumn{5}{|c|}{ - Bering Shelf water } & & \multirow{2}{*}{\multicolumn{2}{|c|}{$\begin{array}{ll}9 & 10\end{array}$}} & \multicolumn{3}{|c|}{ - Anadyr Front - } & \multirow[b]{2}{*}{14} & \multirow[b]{2}{*}{15} \\
\hline & & 2 & 3 & 4 & 5 & 6 & 7 & 8 & & & 11 & 12 & 13 & & \\
\hline Neocalanus plumchrus & 360 & 418 & 358 & 490 & 3 & 1 & 49 & 854 & 30 & 85 & $\mathrm{x}$ & 11 & 65 & $2^{\mathrm{a}}$ & 9 \\
\hline Neocalanus cristatus & 2 & 2 & 3 & 3 & 0 & 0 & 0 & 5 & 3 & 4 & $\mathrm{x}$ & 0 & 1 & 0 & 2 \\
\hline Parathemisto libellula & 0 & 0 & 0 & 0 & 0 & 0 & 1 & 0 & 2 & 0 & 0 & 0 & 0 & 0 & 0 \\
\hline Gammarid amphipod & 0 & 0 & 0 & 0 & 0 & 1 & 0 & 0 & 0 & 0 & 0 & 0 & 0 & 0 & 0 \\
\hline Unidentified amphipod & 0 & 0 & 1 & 0 & 0 & 0 & 0 & 0 & 0 & 0 & 0 & 0 & 0 & 0 & 0 \\
\hline Euphausiid larvae & 0 & 0 & 0 & 0 & 0 & 0 & 0 & 3 & 0 & 0 & 0 & 0 & 0 & 0 & 0 \\
\hline Unidentified Pleustidae & 0 & 2 & 0 & 1 & 0 & 0 & 0 & 17 & 0 & 0 & 0 & 0 & 0 & 0 & 0 \\
\hline Lithode crab larvae & 0 & 0 & 0 & 0 & 0 & 0 & 0 & 1 & 0 & 0 & 0 & 0 & 0 & 0 & 0 \\
\hline Boreogadus sp. & 0 & 0 & 0 & 0 & 4 & 0 & 0 & 0 & 0 & 0 & 0 & 0 & 0 & 0 & 1 \\
\hline Theragra sp. & 3 & 0 & 0 & 0 & 0 & 0 & 0 & 0 & 0 & 0 & 0 & 0 & 0 & 0 & 0 \\
\hline Unidentified fish larvae & 0 & 0 & 1 & 0 & 0 & 0 & 0 & 1 & 0 & 0 & 1 & 0 & 0 & 0 & 0 \\
\hline Unidentified fish bones & 0 & 0 & $\mathrm{x}$ & 0 & 0 & $\mathrm{x}$ & 0 & 0 & 0 & 0 & 0 & 0 & 0 & 0 & 0 \\
\hline Unidentified gadid otolith & 0 & 1 & 0 & 0 & 0 & 0 & 0 & 0 & 0 & 0 & 0 & 0 & 0 & 0 & 0 \\
\hline
\end{tabular}

(Nihoul et al. 1993, Gawarkiewicz et al. 1994), we found the location of the Anadyr Front to be variable: it was not present in the same position among cruises, nor even among days within the same cruise. The distribution of least auklets responded to the movements of the front throughout our study. Large concentrations of least auklets often occurred at the front, and their use of the front appeared to be related to high levels of food availability.

\section{Concentration of zooplankton along the thermocline and in the frontal zone}

Acoustic surveys in both 1985 and 1986 revealed a high biomass of plankton in the vicinity of the front, and also indicated that there was an abrupt change in the vertical distribution of plankton at the front. Whereas most of the acoustically observed plankton biomass was concentrated along the thermocline on the stratified side of the front, available evidence suggests that plankton was thoroughly mixed in the turbulent waters west of the front. Concentration of copepods along the thermocline is consistent with previous observational and experimental studies, which have demonstrated that aggregations of zooplankton often occur at property interfaces (Harder 1968, Turner \& Dagg 1983)

Direct net sampling indicated that calanoid copepods were the numerically dominant component of the zooplankton, and that copepod densities were significantly enhanced in the frontal zone. Previous studies have found copepod concentrations in association with a wide variety of frontal features. For example, Mackas
\& Louttit (1988) documented concentrations of Neocalanus plumchrus along the margin of the Fraser River outflow plume. Herman et al. (1981) found that copepod abundance was 3 to 4 times greater at the shelfbreak front south of Nova Scotia than in adjacent waters. Cooney (1981) showed that copepod biomass was enhanced along the shelfbreak front in the southeastern Bering Sea, and Wishner et al. (1995) found peak densities of Calanus finmarchicus associated with a salinity front of Cape Cod, Massachusetts. Copepod concentrations have also been documented in the vicinity of upwelling fronts off California (Smith et al. 1986).

The causes of such frontal concentrations have been widely debated, and may vary geographically and/or temporally. Sustained chemical fluxes and nutrient regeneration in frontal zones can maintain persistent phytoplankton blooms (e.g. Traganza et al. 1987, Dewey \& Moum 1993), which may potentially drive an upward cascade of trophic interactions through food chains (i.e. via aggregation of organisms at higher trophic levels to feed on growing biomass concentrations at lower levels; Atkinson \& Targett 1983). However, zooplankton concentrations can also be generated in the absence of enhanced primary production purely through mechanical accumulation resulting from the hydrodynamic convergence associated with fronts (Olson \& Backus 1985, Franks 1992b, Govoni \& Grimes 1992).

Concentration of copepods in the Anadyr Front likely was not due to enhanced production, because the ontogenetic development of most of the copepod species present occurs well to the south of the study area in early spring (Cooney \& Coyle 1982, Vidal \& 
Smith 1986, Miller \& Clemons 1988). Instead, concentration was probably caused by mechanical accumulation as a result of hydrographic processes. Results from theoretical studies of frontogenesis in shallow seas (James 1978, Wang 1984) indicate that the Anadyr Front is probably maintained by strong surface convergence along the boundary between the Anadyr Stream and Bering Shelf water. Species that are positively buoyant should tend to accumulate in zones of surface convergence and downwelling. Subsurface concentrations also may form, depending on circulation and each species' response to flow patterns (Franks 1992b). Wishner et al. (1995) showed that the distribution of peak copepod abundance in the Gulf of Maine varied between years in concert with a shift in the location of areas of surface current convergence.

\section{Diet and habitat selection by least auklets}

Our finding that least auklets were feeding preferentially on Neocalanus plumchrus is in agreement with most previous trophic studies of this bird (Bédard 1969, Searing 1977, Bradstreet 1985, Springer \& Roseneau 1985, Springer et al. 1986, 1987, Harrison 1987, 1990, Day \& Byrd 1989, Hunt \& Harrison 1990, Hunt et al. 1990, 1993, Piatt et al. 1990b, Obst et al. 1995). There was no evidence that least auklets took Eucalanus bungii at the front, despite the fact that it outnumbered $N$. plumchrus by a factor of 5 (Table 1) and these copepods are about the same size ( $-6 \mathrm{~mm}$ length). However, the energy value of $N$. plumchrus is 2.5 times greater than that of $E$. bungii. Selection of copepod prey by least auklets therefore appears to be dictated primarily by the energy content of individual prey items rather than the relative abundance of the different potential prey species, which is consistent with predictions about diet selection from optimal foraging models (Stephens \& Krebs 1986). E. bungii is also more transparent than $N$. plumchrus, and might be more difficult to see underwater. Some workers have suggested that seabirds are generally opportunistic taking whatever prey are available at a given place and time (e.g. Ainley et al. 1992). Our data, together with previous studies (Hunt \& Harrison 1990, Hunt et al. 1990, Obst et al. 1995), clearly indicate that least auklets are not random samplers of their marine environment, but instead are highly selective in their diet.

\section{Use of the front by least auklets}

The Anadyr Current is the proximate source of the copepods upon which least auklets preyed. However, west of the front in unstratified Anadyr water, cope- pods were presumably dispersed uniformly throughout the water column by the intense turbulence, and were probably difficult to exploit profitably. Haney (1991) asserted that least auklets preferentially occurred in mixed waters in the Anadyr Strait, but his analyses did not discuss the role of the front, rendering his conclusions difficult to assess critically.

Our net sampling indicated that Neocalanus plumchrus occurred abundantly east of the front in the stratified water. These oceanic copepods are presumably introduced into the eastern side of the strait via the subsurface intrusion of Anadyr water, and may subsequently be injected into the upper layer of Bering Shelf water via mixing across the thermocline, as suggested by some of our hydroacoustic surveys (e.g. Figs. $3 \& 4 \mathrm{~B}$ ). Despite the occurrence of $N$. plumchrus in stratified water, many least auklets overflew this water to feed at the front. Enhanced availability of $N$. plumchrus therefore must have been the principal reason why these birds usually travelled so far from their colonies to feed at the front.

Least auklets, like other alcids, have a specialized flight morphology (specifically, reduced wing area) that results in a high energetic cost of flight; these birds therefore are expected to forage as close to their colonies as is economically feasible (Obst et al. 1995). In all transects where we observed large concentrations of least auklets away from the front, net samples and/or hydroacoustic surveys demonstrated high levels of food availability where the birds were feeding. In the one instance where we conducted a net tow in the vicinity of a least auklet concentration away from the front, the net sample indicated that the birds were exploiting an extremely dense patch of Neocalanus plumchrus in stratified Bering Shelf water (Fig. 7). When we exclude this data point, the mean density of $N$. plumchrus in waters overflown by least auklets averaged 15.5 ind. $\mathrm{m}^{-3}$. This suggests that there may be a threshold density of $N$. plumchrus below which it is economically infeasible for least auklets to forage, and that this threshold is $\geq 16$ ind $\mathrm{m}^{-3}$. The precise threshold value is difficult to estimate, because our nets sampled deeper parts of the water column that were inaccessible to least auklets (maximum diving depth estimated to be about $15 \mathrm{~m}_{\text {; }}$ Obst et al. 1995), and the integrated water-column densities therefore may not accurately reflect the availability of copepods to foraging auklets.

While concentrations of least auklets were frequently associated with the Anadyr Front, their abundance at the front varied dramatically. Some of this variation was undoubtedly attributable to diel patterns of foraging and colony attendance (Piatt et al. 1990a), which we did not study. We suspect, however, that some of the variation may also reflect frontal dynamics. 
Fronts have been popularly conceptualized as unitary structures with predictable dynamics, but this view is probably oversimplified. Recent workers have recognized that frontal zones are characterized by complex internal structure and may incorporate features across a wide range of spatial scales (Rodionov 1994). For example, recent studies of the Mississippi River plume front have indicated that the frontal system consists of a large-scale $(-2-20 \mathrm{~km}$ width) frontal zone within which are embedded small-scale $(-10-50 \mathrm{~m}$ width) convergence zones (Govoni \& Grimes 1992). Furthermore, although there was evidence of overall concentration of larval fishes in surface waters in the frontal zone, exceptionally high densities were not observed regularly at the small-scale features (Govoni \& Grimes 1992). The small-scale convergence zones were sinuous in shape and were ephemeral, forming and dissipating over time scales of 2 to $6 \mathrm{~h}$. They were not always observed during transects across the largescale zone. Govoni \& Grimes (1992) suggested that 'densities of larval fishes within the [large-scale] frontal zone are probably the result of their accumulation along ephemeral convergence zones and subsequent dispersal and mixing during relaxation of convergence', and that the spatial distribution of larvae in the vicinity of the front is consequently 'the aggregate result of the repeated formation and degeneration of [small-scale] convergence zones.' Olson et al. (1994) also distinguished between large-scale frontal zones and fronts, arguing that the primary biological response ... is tied to the dynamics of the smaller scale features, i.e., the individual fronts, that are characteristic of these frontal zones'.

Although our CTD sections indicated that the front itself was very sharp, we have no information on the flow dynamics and circulation patterns. However, our visual observations while crossing the strait indicated that the presence of a surface manifestation of the front was variable. During one crossing of the front in 1986 we observed surface-feeding birds foraging in a narrow line along a slick which apparently represented the surface expression of the front. During most other crossings, there were few visual cues marking the presence of the front. Variability in the surface manifestation of the front may adversely affect the auklets' ability to locate it and/or track it accurately. Supporting evidence comes from our observation of a least auklet concentration that persisted at the same site for 2 consecutive days, despite the fact that the front had moved out of the area by the second day (Fig. 8A, B). We also suspect that circulation patterns associated with the Anadyr Front are more complex than is otherwise suggested by the strikingly uniform CTD sections. Variability in kinematic structure may affect the extent to which cope- pod concentrations develop and persist in the frontal zone, and consequently affect the birds' use of the front. A cross-front hydroacoustic survey supported these ideas, demonstrating a complex multimodal pattern of zooplankton concentration near the surface (Fig. 8C).

\section{Distribution of crested auklets}

In contrast to least auklets, crested auklets, when found, were usually away from the front in areas without any striking hydrographic features. On transects where they were encountered, crested auklets consistently occurred in compact aggregations that were clearly separated from least auklets and on the nearshore side of the front. This spatial segregation of the 2 species could have resulted from (1) differences in flight capabilities, (2) interspecific competition, or (3) dietary differences.

Within any group of bird species that differ in size but are otherwise morphologically and ecologically similar, flight mechanics theory (Pennycuick 1989) dictates that larger species can fly faster and therefore have larger potential foraging radii. Thus, there will be some habitats potentially exploitable by larger species that cannot be used by smaller species. This foraging radius hypothesis can clearly be rejected here, because crested auklets are larger ( $\sim 280 \mathrm{~g}$ vs $\sim 80 \mathrm{~g})$ and therefore have a larger potential foraging radius than least auklets, yet crested auklets were usually found closer to their breeding sites.

Previous workers have proposed that differences in foraging zones at sea have evolved as an ecological isolating mechanism in response to historic interspecific competition in alcid communities (Cody 1973; but see Bédard 1976). In other words, differences in foraging distributions may reflect evolutionary niche differentiation, or the 'ghost of competition past' (sensu Connell 1980). Fixed foraging zones or preferred foraging distances also seem unlikely in our study, because the pattern of separation between the 2 species sometimes reversed (i.e. crested auklets were found farther from St. Lawrence Island than least auklets in several instances). Spatial segregation could, however, result from competition in the present. This possibility is difficult to evaluate because we have no direct evidence either for or against competition, and furthermore there is little consensus in the literature about whether interspecific competition is an important factor underlying patterns of space use in seabirds. The problem is especially difficult for diving birds because their submarine behavior during foraging bouts is invisible to shipboard observers. However, observations of alcids by Duffy et al. (1987) in an artificial environment indi- 
cated that aggressive interactions are common underwater, and Duffy et al. suggested that underwater interspecific interactions may be involved in the partitioning of space among different species. Whether competition can cause spatial segregation in planktivorous seabirds awaits further study.

The most likely explanation for the observed patterns of spatial segregation is that different physical factors influenced the availability of the 2 species' preferred prey. In 2 instances, concentrations of crested auklets were located over acoustically observed epibenthic scattering layers (Figs. 4A \& 8C), which probably consisted primarily of euphausiids. Although we were not able to collect diet samples from crested auklets in this study and do not know with certainty what the birds were eating, available information on the diet of crested auklets elsewhere in the northern Bering Sea generally points to euphausiids as their principal prey during the chick-rearing period. On St. Lawrence Island, Bédard (1969) found that crested auklets fed mostly on Thysanoessa spp. Similarly, collections of foraging crested auklets in the Chirikov Basin indicated that $T$. raschii was the most important prey type, though copepods and amphipods were also taken (Harrison 1987). Piatt et al. (1988) and Haney \& Solow (1992) also reported that Thysanoessa spp. were the dominant prey taken by crested auklets off St. Lawrence Island. Further south, Hunt et al. (1981) examined auklet diets at the Pribilof Islands and found that crested auklets took mostly euphausiids ( $69 \%$ by volume, primarily $T$. inermis), together with substantial numbers of amphipods $(30 \%$ by volume, primarily Parathemisto libellula).

Euphausiids may be concentrated by topographically forced upwellings if they attempt to remain at depth by swimming downward (Simard et al. 1986), and in these circumstances may then be exploited easily by seabirds (e.g. Coyle et al. 1992). On 1 of our transects, a strong upward excursion of the thermocline was evident in CTD data in the area where we observed crested auklets foraging over a distinct epibenthic scattering layer (Fig. 4A). If this 'dome' was caused by subsurface upwelling, it may have been a source of enhanced euphausiid density via the mechanism previously described. Alternatively, domes of deep Anadyr water intruding into the overlying Bering Shelf water may represent discrete areas where Anadyr water enters the Chirikov Basin as a strong subsurface jet. This interpretation is supported by our observations of the plankton net's wire angle during some vertical tows, which suggested considerable current shear. We hypothesize that crested auklets may exploit euphausiids that are advected by rapidly moving subsurface jets of Anadyr water along the eastern side of the strait. By positioning themselves over such jets, crested auklets may realize an increase in the effective availability of their euphausiid prey-even in the absence of any real variation in prey densitybecause the rate of contact with individual prey items should increase. Interestingly, when the deformation in the thermocline relaxed following the completion of the transect just described, the epibenthic scattering layer disappeared completely and the concentration of crested auklets dispersed (Fig. 4B; cf. Fig. 4A).

In most cases where we encountered crested auklets, no striking hydrographic features were evident (Figs. 6, 7, 8A,C \& 9). We speculate that on some transects, our CTD casts may have been too coarsely spaced to resolve the fine structure associated with hydrographic features important to crested auklets.

\section{Role of the Anadyr Front in the northern Bering Sea ecosystem}

Some previous workers have suggested that fronts act as boundaries between marine communities (Brandt \& Wadley 1981; but see Sournia 1994). This does not appear to be the case in the Anadyr Strait, because differences in zooplankton species composition between water masses are manifested primarily in relative differences in densities of the constituent species, rather than in absolute taxonomic composition (Table 1; see also Springer et al. 1989, Piatt et al. 1992). While the Anadyr Front cannot be characterized as a biogeographic boundary, it is a feature that supports elevated zooplankton populations. In turn, enhanced availability of preferred copepod prey associated with this front attracts large numbers of foraging least auklets. Crested auklets generally did not occur at the front, and instead may have been exploiting enhanced fluxes of euphausiids being advected by subsurface jets on the eastern side of the strait. Thus, spatial segregation of the 2 principal planktivores in the Anadyr Strait likely arises because of their use of different prey originating at different depths. All prey taken by auklets probably originates within same system (i.e. the Anadyr Current), but apparently different physical mechanisms are responsible for the localized enhancement of availability of the 2 prey types. Hunt et al. (1998) reached qualitatively similar conclusions concerning a physical oceanographic basis to niche differentiation among auklets around the Aleutian Islands.

Large auklet colonies are distributed mostly along the western tip and northwestern side of St. Lawrence Island (Fig. 1). We suspect that this distribution reflects the predictability and economy of prey availability, and that the Anadyr Front may be important for supporting the large local populations. Despite the variability of the front over short time scales, the avail- 
ability of the front (and associated concentrations of plankton) appears to be highly predictable over the long term. The presence of this front may therefore be one of the most important factors controlling the reproductive performance of least auklets in the region. Auklets need the Anadyr Current for successful feeding, because this current carries their preferred prey. However, they also need a structured water column, because strong turbulence and intense mixing undoubtedly preclude the formation of plankton patches in pure Anadyr water.

Unfortunately, little is currently known about the ecological consequences of the intense interannual variability in physical and biological processes that affects the region. Physical variability is manifested in year-to-year changes in the eastward extent of excursions of the Anadyr Current into the Chirikov Basin and around St. Lawrence Island (Coachman \& Aagaard 1988, Coachman 1993, Gawarkiewicz et al. 1994). There is undoubtedly also intense interannual variability in zooplankton source populations (Sambrotto \& Goering 1983, Smith \& Vidal 1986), but little is currently known about how (or whether) this affects the northern Bering Sea ecosystem. Regardless of how interannual variability is manifested (i.e. eastward excursions of Anadyr water vs changes in the composition and/or abundance of zooplankton populations), we hypothesize that the proximity of the Anadyr Front may buffer least auklets breeding along the western side of. St. Lawrence Island against depressions in prey availability compared to auklets breeding farther east on the island. Indeed, we discovered from conversations with the native people of Savoonga that auklets suffered a near-total reproductive collapse on central St. Lawrence Island in 1984: few birds layed eggs, and most of the occupied nests were subsequently deserted. Additionally, many birds washed ashore dead late in the summer of 1984. In the following year (1985), large numbers of birds bred and their nesting appeared to be successful. Bédard (1969) also observed large numbers of starving crested auklets on the north side of St. Lawrence Island in one year. This anecdotal evidence of occasional large-scale reproductive failure and adult mortality suggests that perturbations in the Anadyr Current may have profound effects on auklet populations, though the exact mechanisms are not clear. Long-term multidisciplinary studies will be required to understand fully how the interplay between physical and biological processes in the region affects the foraging success and reproductive performance of these interesting planktivorous birds.

Acknowledgements. We thank K. Coyle, Z. Eppley, B. Obst, R. Veit, M. Whitehouse, C. Williams, and B. Young for field assistance during the 1984-1986 cruises, and J. M. Grebmeier for providing the opportunity for us to join the 1993 cruise. We also thank the captain and crew of the RV 'Alpha Helix' for outstanding logistical support, and $R$. Veit and 4 anonymous reviewers for comments on an earlier draft of the paper. Financial support was provided by NSF grants DPP-8308232 and DPP-9321636 (to G.L.H.) and DPP-9300694 (to J. M. Grebmeier and L. W. Cooper).

\section{LITERATURE CITED}

Ainley DG, Ribic CA, Fraser WR (1992) Does prey preference dffect habitat choice in Antarctic seabirds? Mar Ecol Prog Ser 90:207-221

Atkinson LP, Targett TE (1983) Upwelling along the 60-m isobath from Cape Canaveral to Cape Hatteras and its relationship to fish distribution. Deep-Sea Res 30:221-226

Bédard J (1969) Feeding of the least, crested and parakeet auklets around St. Lawrence Island, Alaska. Can J Zool 47:1025-1050

Bédard J (1976) Coexistence, coevolution and convergent evolution in seabird communities: a comment. Ecology 57 : $177-184$

Beebe W (1926) The Arcturus adventure. Putnam, New York

Bell GP (1990) Birds and mammals on an insect diet: a primer on diet composition analysis in relation to ecological energetics. Stud Avian Biol 13:416-422

Bradstreet MSW (1985) Chapter IV. Feeding studies. In: Johnson SR (ed) Population estimation, productivity, and food habits of nesting seabirds at Cape Peirce and the Pribilof Islands, Bering Sea, Alaska. Report by LGL Ecological Research Associates, Inc, to Minerals Management Service, Anchorage, AK, p 257-306

Brandt SB, Wadley VA (1981) Thermal fronts as ecotones and zoogeographic barriers in marine and freshwater systems. Proc Ecol Soc Aust 11:13-26

Brown CW, Winn HE (1989) Relationship between the distribution pattern of right whales, Eubalaena glacialis, and satellite-derived sea surface thermal structure in the Great South Channel. Cont Shelf Res 9:247-260

Carey FG, Robison BH (1981) Daily patterns in the activities of swordfish. Xiphias gladius, observed by acoustic telemetry. Fish Bull 79:277-292

Coachman LK (1993) On the flow field in the Chirikov Basin. Cont Shelf Res 13:481-508

Coachman LK, Aagaard K (1988) Transport through Bering Strait: annual and interannual variability. J Geophys Res 93:15535-15539

Coachman LK, Aagaard K, Tripp RB (1.975) Bering Strait: the regional physical oceanography. University of Washington Press, Seattle

Cody ML (1973) Coexistence, coevolution and convergent evolution in seabird communities. Ecology 54:31-44

Connell JH (1980) Diversity and the coevolution of competitors, or the ghost of competition past. Oikos 35:131-138

Cooney RT (1981) Bering Sea zooplankton and micronekton communities with emphasis on annual production. In: Hood DW, Calder JA (eds) The eastern Bering Sea shelf oceanography and resources, Vol 2. Office of Marine PolIution Assessment, NOAA, Juneau, AK, p 947-974

Cooney RT, Coyle KO (1982) Trophic implications of crossshelf copepod distributions of the southeastern Bering Sea. Mar Biol 70:187-196

Coyle KO, Hunt GL, Decker MB, Weingartner TJ (1992) Murre foraging, epibenthic sound scattering and tidal advection over a shoal near St. George Island, Bering Sea. Mar Ecol Prog Ser 83:1-14 
Darwin C (1845) Journal of researches into the natural history and geology of the countries visited during the voyage of $H$. M. S. Beagle round the world, under the command of Capt. Fitz Roy, R.N. John Murray, London

Day RH, Byrd GV (1989) Food habits of the Whiskered Auklet at Buldir Island, Alaska. Condor 91:65-72

Dewey RK, Moum JN (1993) Enhancement of fronts by vertical mixing. J Geophys Res 95:9433-9445

Duffy DC, Todd FS, Siegfried WR (1987) Submarine foraging behavior of alcids in an artificial environment. Zoo Biol $6: 373-378$

Dufour P, Stretta JM (1973) Fronts thermiques et thermohalins dans la région du Cap Lopez (golf du Guinée) juinjuillet 1972: phytoplancton, zooplancton, micronekton et pafeche thonière. Doc Sci Cent Rech Océanogr (Abidjan, Cote d'Ivoire) 4:99-142

Epifanio CE (1987) The role of tidal fronts in maintaining patches of brachyuran zoeae in estuarine waters. J Crustac Biol 7:513-517

Fay FH, Cade TJ (1959) An ecological analysis of the avifauna of St. Lawrence Island, Alaska. Univ Calif Publ Zool 63: $73-150$

Fay FH, Kelly BP, Gehnrich PH, Sease JL, Hoover AA. (1984) Modern populations, migrations, demography, trophics, and historical status of the Pacific walrus. Final Report. Institute of Marine Science, University of Alaska, Fairbanks

Fedorov KN (1986) The physical nature and structure of oceanic fronts. Springer-Verlag, Berlin

Fernandez E, Bode A, Botas A, Anadon R (1994) Microplankton assemblages associated with saline fronts during a spring bloom in the central Cantabrian Sea: differences in trophic structure between water bodies. J Plankton Res 13:1239-1256

Fiedler PC, Bernard HJ (1987) Tuna aggregation and feeding near fronts observed in satellite imagery. Cont Shelf Res $7: 871-881$

Floodgate GD, Fogg GE, Jones DA, Lochte K, Turley CM (1981) Microbiological and zooplankton activity at a front in Liverpool Bay. Nature 290:133-136

Franklin B (1786) A letter from Dr. Benjamin Franklin, to Mr. Alphonsus le Roy, member of several academies, at Paris. Containing sundry maritime observations. Trans Am Philos Soc 2:294-329

Franks PJS (1992a) Phytoplankton blooms at fronts: patterns, scales, and physical forcing mechanisms. Rev Aquat Sci 6:121-137

Franks PJS (1992b) Sink or swim: accumulation of biomass at fronts. Mar Ecol Prog Ser 82:1-12

Gaskin DE (1987) Updated status of the Right Whale, Eubalaena glacialis, in Canada. Can Field-Nat 101:295-309

Gawarkiewicz G, Haney JC, Caruso MJ (1994) Summertime synoptic variability of frontal systems in the northern Bering Sea. J Geophys Res 99:7617-7625

Govoni JJ, Grimes CB (1992) The surface accumulation of larval fishes by hydrodynamic convergence within the Mississippi River plume front. Cont Shelf Res 12:1265-1276

Gudkov VM (1962) Relationship between the distribution of zooplankton, sea birds and baleen whales. Tr Inst Okeanol Akad Nauk SSSR 58:298-313 (translated from Russian by the Department of the Navy, Naval Oceanographic Office, Washington, DC, 1974)

Haney JC (1991) Influence of pycnocline topography and water-column structure on marine distributions of alcids (Aves: Alcidae) in Anadyr Strait, Northern Bering Sea, Alaska. Mar Biol 110:419-435

Haney JC, Solow AR (1992) Testing for resource use and selection by marine birds. J Field Ornithol 63:43-52
Hansell DA, Goering JJ, Walsh JJ, McRoy CP, Coachman LK, Whitledge TE (1989) Summer phytoplankton production and transport along the shelf break in the Bering Sea. Cont Shelf Res 9:1085-1104

Hansell DA, Whitledge TE, Goering JJ (1993) Patterns of nitrate utilization and new production over the BeringChukchi shelf. Cont Shelf Res 13:601-627

Harder W (1968) Reactions of plankton organisms to water stratification. Limnol Oceanogr 13:156-168

Harrison NM (1987) Foraging behavior and coexistence of seabirds in the Bering Sea. PhD dissertation, University of California, Irvme

Harrison NM (1990) Gelatinous zooplankton in the diet of the Parakeet Auklet: comparisons with other auklets. Stud Avian Biol 14:114-124

Harrison NM, Hunt GL Jr, Cooney RT (1990) Front affecting the distribution of seabirds in the northern Bering Sea. Polar Res 8:29-31

Hawke DJ (1996) Relatively infrequent seabird aggregation at nearshore fronts and tidal plumes at locations around Banks Peninsula, New Zealand. Notornis 43:66-70

Herman AW, Sameoto DD, Longhurst AR (1981) Vertical and horizontal distribution patterns of copepods near the shelf break south of Nova Scotia. Can J Fish Aquat Sci 38: $1065-1076$

Herron RC, Leming TD, Li J (1989) Satellite-detected fronts and butterfish aggregations in the northeastern Gulf of Mexico. Cont Shelf Res 9:569-588

Highsmith RC, Coyle KO (1990) High productivity of northern Bering Sea amphipods. Nature 344:8662-8664

Hunt GL Jr, Harrison NM (1990) Foraging habitat and prey taken by least auklets at King Island, Alaska. Mar Ecol Prog Ser 65:141-150

Hunt GL Jr, Schneider DC (1987) Scale-dependent processes in the physical and biological environment of marine birds. In: Croxall JP (ed) Seabirds: feeding ecology and role in marine ecosystems. Cambridge University Press, Cambridge, p 7-41

Hunt GL Jr, Burgeson B, Sanger GA (1981) Feeding ecology of seabirds of the eastern Bering Sea. In: Hood DW. Calder JA (eds) The eastern Bering Sea shelf: oceanography and resources, Vol 2. University of Washington Press, Seattle, p 629-647

Hunt GL Jr, Harrison NM, Cooney RT (1990) The influence of hydrographic structure and prey abundance on foraging of Least Auklets. Stud Avian Biol 14:7-22

Hunt GL Jr, Harrison NM, Piatt JF (1993) Foraging ecology as related to the distribution of planktivorous auklets in the Bering Sea. In: Vermeer K, Briggs KT, Morgan KH, SiegelCausey D (eds) The status, ecology: and conservation of marine birds of the North Pacific. Canadian Wildlife Service Special Publication, Ottawa, p 18-26

Hunt GL Jr, Russell RW, Coyle KO, Weingartner T (1998) Comparative foraging ecology of planktivorous auklets in relation to ocean physics and prey availability. Mar Ecol Prog Ser 167:241-259

Iverson RL, Whitledge TE, Goering JJ (1979) Chlorophyll and nitrate fine structure in the southeastern Bering Sea shelf break front. Nature 281:664-666

James ID (1978) A note on the circulation induced by a shallow-sea front. Estuar Coast Mar Sci 7:197-202

Johnson KR, Nelson CH (1984) Side-scan sonar assessment of gray whale feeding in the Bering Sea. Science 225 $1150-1152$

Johnson MW (1963) Zooplankton collections from the high Polar Basin with special reference to the Copepoda Limnol Oceanogr 8:89-102 
Kinder TH, Chapman DC, Whitehead JA Jr (1986) Westward intensification of the mean circulation on the Bering Sea shelf. J Phys Oceanogr 16:1217-1229

Laubscher RK, Perissinotto R, MCQuaid CD (1993) Phytoplankton production and biomass at frontal zones in the Atlantic sector of the Southern Ocean. Polar Biol 13: $471-481$

Laurs RM, Lynn RJ (1977) Seasonal migration of North Pacific albacore, Thunnus dldlumici, into North American coastal waters: distribution, relative abundance and association with transition zone waters. Fish Bull 75:795-822

Le Fèvre $J$ (1986) Aspects of the biology of frontal systems Adv Mar Biol 23:163 299

Mackas DL, Louttit Gl: (1988) Aggregation of the copepod Neocalanus plumchrus at the margin of the Fraser River plume in the Strait of Georgia. Bull. Mar Sci 43:810-824

Maul GA, Williams F, Roffer M, Sousa FM (1984) Variability in Gulf of Mexico longline bluefin tuna catches, 1979-1980, in relation to environmental conditions studied using ships and satellites. Oceanol Acta 7:469-479

McRoy CP, Hansell DA, Springer AM, Waish JJ, Whitledge TE (1987) Global maximum of primary production in the north Bering Sea. EOS 68:17-27

Miller CB (1988) Neocalanus flemingeri, a new species of Calaniclae (Copepoda: Calanoida) from the subarctic Pacific Ocean, with a comparative redescription of Neocalanus plumchrus Maruhawa. Prog Oceanogr 20:223-273

Miller CB. Clemons MJ (1988) Revised life history analysis for large grazing copepods in the subarctic Pacific Ocean. Prog Oceanogr 20:293-313

Nasu K (1974) Movement of baleen whales in relation to hydrographic conditions in the northern part of the north Pacific Ocean and the Bering Sea. In: Hood DW, Kelley EJ (eds) Oceanography of the Bering Sea, with emphasis on renewable resources. Institute of Marine Science, University of Alaska, Fairbanks, p 345-361

Nelson $\mathrm{CH}$, Johnson KR (1987) Whales and walruses as tillers of the sea floor. Sci im 255(2):112-117

Nerini M (1984) A review of gray whale feeding ecology. In: Jones ML, Swartz SL, Leatherwood S (eds) The gray whale Eschrichtius robustus. Academic Press, Orlando, FL, p $423 \quad 450$

Nihoul JCJ, Adam P, Brasseur P, Deleersnijder E, Djenidi S, Haus J (1993) Three-dimensional general circulation model of the northern Bering Sea's summer ecohydrodynamics. Cont Shelf Res 13:509-542

Obst BS, Hunt GL Jr (1990) Marine birds feed at gray whale mud plumes in the Bering Sea. Auk 107:678-688

Obst BS, RusseIl RW, Hunt GL. Jr, Eppley ZA., Harrison NM (1995) Foraging radii and energetics of least auklets (Aethia pusilla) breeding on three Bering Sea Islands Physiol Zool 68:647-672

Olson DB, Backus RH (1985) The concentrating of organisms at fronts: a cold-water fish and a warm-core Gulf Stream ring. J Mar Res 43:113-137

Olson DB, Podestá GP (1987) Ocean tronts as pathways in the sea. In: Herrnkind WF, Thistle AB (eds) Signposts in the sea. Florida State University, Tallahassee, p $1-14$

Olson DB, Hitchcock GL, Mariano AJ, Ashjian CJ, Peng G, Nero RW, Podestá GP (1994) Life on the edge: marine life and fronts. Oceanography 7:52-60

Overland JE, Stabeno PJ, Salo S (1996) Direct evidence for northward flow on the northwestern Bering Sea shelf. J Geophys Res 101C:8971-8976

Pennycuick CJ (1989) Bird flight performance: a practical calculation manual. Oxford University Press, Oxford

Piatt JF, Hatch SA, Roberts BD, Lidster WW, Wells JL, Haney
JC (1988) Populations, productivity, and feeding habits of seabirds on St. Lawrence Island. Final Report, OCS Study MMS 88-0022, US Fish and Wildlife Service, Anchorage, AK

Piatt JF, Roberts BD, Hatch SA (1990a) Colony attendance and population monitoring of Least and Crested Auklets on St. Lawrence Island, Alaska. Condor 92:97-106

piatt JF, Roberts BD, Lidster WW, Wells JL, Hatch SA (1990b) Effects of human disturbance on breeding Least and Crested Auklets at St. Lawrence Island, Alaska. Auk 107:342-350

Piatt JF, Pinchuk A, Kitaiskiy A (1992) Auklets, eddies, and plankton in Bering Strait. In: Piatt JF, Pinchuk A, Kitaiskiy A, Springer AM, Hatch SA (eds) Foraging distribution and feeding ecology of seabirds at the Diomede Islands, Bering Strait. US Fish and Wildlife Service Final Report for. Minerals Management Service loCs Study MMS 920041), Anchorage, AK, p 1-76

Podesta GP, Browder JA, Hoey JJ (1993) Exploring the association between swordfish catch rates and thermal fronts on U.S. longline grounds in the western North Allantic. Cont Shelf Res 13:253-277

Rodionov VB (1994) Mechanisms of formation of internal structure of frontal zones in Norwegian and Greenland Seas. Oceanology 33:567-576

Sambrotto RN, Goering JJ (1983) Interannual variability of phytoplankton and zooplankton production on the southeast Bering Sea shelf. In: Wooster WS (ed) From year to year: interannual variability of the environment and fisheries of the Gulf of Alaska and the eastern Bering Sea. University of Washington, Seattle, p 161-177

Sambrotto RN, Goering JJ, McRoy CP (1984) Large yearly production of phytoplankton in the western Benng Strait. Sclence 225:1147-1150

Schneider DC (1990) Seabirds and fronts: a brief overview. Polar Res 8:17-21

Schneider DC (1991) The role of fluid dynamics in the ecology of marine birds. Oceanogr Mar Biol Annu Rev 29:487-521

Schneider D, Harrison NM, Hunt GL Jr (1987) Variation in the occurrence of marine birds at fronts in the Bering Sea. Estuar Coast Shelf Sci 25:135-141

Searing GF (1977) Some aspects of the ecology of cliff-nesting seabirds at Kongkok Bay, St. Lawrence Island, Alaska, during 1976. OCSEAP, Outer Continental Shelf Environmental Assessment Program, Annu Rep 5:263-412

Simard $Y$, de Ladurantaye $R$, Therriault J (1.986) Aggregation of euphausiids along a coastal shelf in an upwelling environment. Mar Ecol Prog Ser 32:203-215

Sinclair E, Loughlin T, Pearcy W (1994) Prey selection by northern fur seals (Callorhinus ursinus) in the eastern Bering Sea. Fish Bull 92:144-156

Smith SL, Vidal J (1986) Variations in the distribution, abundance, and development of copepods in the southeastern Bering Sea in 1980 and 1981. Cont Shelf Res 5: $215-240$

Smith SL, Jones BH, Atkinson LP, Brink KH (1986) Zooplankton in the upwelling fronts off Point Conception, California. In: Nihoul JCJ (ed) Marine interfaces ecohydrodynamics. Elsevier, Amsterdam, p 195-213

Sournia A (1994) Pelagic biogeography and fronts. Prog Oceanogr 34:109-120

Sowls AL, Hatch SA, Lensink CJ (1978) Catalog of Alaskan seabird colonies. US Department of the Interior, Fish and Wildlife Service, FWS/OBS-78/78

Springer AM, MicRoy CP (1993) The paradox of pelagic food webs in the northern Bering Sea-III. Patterns of primary production. Cont Shelf Res 13:575-599 
Springer AM, Roseneau DG (1985) Copepod-based food webs: auklets and oceanography in the Bering Sea. Mar Ecol Prog Ser 21:229-237

Springer AM, Roseneau DG, Lloyd DS, McRoy CP, Murphy EC (1986) Seabird responses to fluctuating prey availability in the southeastern Bering Sea. Mar Ecol Prog Ser $32: 1-12$

Springer AM, Murphy EC, Roseneau DG, McRoy CP, Cooper BA (1987) The paradox of pelagic food webs in the northern Bering Sea-1. Seabird food habits. Cont Shelf Res 7:895-911

Springer AM, McRoy CP, Turco KR (1989) The paradox of pelagic food webs in the northern Bering Sea-II. Zooplankton communities. Cont Shelf Res 9:359-386

Stephens D, Krebs JR (1986) Foraging theory. Princeton University Press, Princeton

Stigebrandt A (1984) The North Pacific: a global-scale estuary. J Phys Oceanogr 14:464-470

Traganza ED, Redalje DG, Garwood RW (1987) Chemical flux, mixed layer entrainment and phytoplankton blooms

Editorial responsibility: Otto Kinne (Editor),

Oldendorf/Luhe, Germany at upwelling fronts in the California coastal zone. Cont Shelf Res 7:89-105

Turner JT, Dagg MJ (1983) Vertical distributions of continental shelf zooplankton in stratified and isothermal waters. Biol Oceanogr 3:1-40

Uda M (1938) Researches in 'Siome' or current rip in the sea. Geophys Mag 11:307-372

Vidal J, Smith SL (1986) Biomass, growth, and development of populations of herbivorous zooplankton in the southeastern Bering Sea during summer. Deep-Sea Res 33 $523-556$

Wang DP (1984) Mutual intrusion of a gravity current and density front formation. J Phys Oceanogr 14:1191-1199

Wishner KF, Schoenherr JR, Beardsley R, Chen C (1995) Abundance, distribution and population structure of the copepod Calanus finmarchicus in a springtime right whale feeding area in the southwestern Gulf of Maine. Cont Shelf Res 15:475-507

Yoder JA, Ackleson SG, Barber RT, Flament P, Balch WM (1994) A line in the sea. Nature 371:689-692

Submitted: December 30, 1997; Accepted: September 28, 1998 Proofs received from author(s): May 6, 1999 